\title{
SOCIEDADE DE RISCO, PRINCÍPIO DA PRECAUÇÃO E DEMOCRACIA \\ O CASO DOS TRANSGÊNICOS
}

Marijane Vieira Lisboa ${ }^{1}$

\section{RESUMO}

$\mathrm{Na}$ modernidade avançada, a produção social da riqueza é sistematicamente acompanhada pela produção de riscos, riscos produzidos justamente pelos avanços científicos e técnicos, constituindo aquilo que Ulrich Beck chamou de Sociedade de Risco. Seria possível evitar tais riscos, caso se adotasse o Princípio da Precaução, previsto nas legislações ambientais internacionais e nacionais, mas os interesses econômicos e políticos relacionados com a privatização do conhecimento resistem a processos democráticos de deliberação.

Palavras chave: Sociedade de risco; Princípio da precaução; Transgênicos.

É uma ideia bastante aceita entre cientistas sociais o fato de que a Ciência e a tecnologia tenham substituído a religião nos tempos modernos, enquanto concepção de mundo, critério de verdade e valor supremo. A confiança que nossa época moderna deposita na Ciência é efetivamente enorme, dela esperando-se a solução e o remédio para muitos problemas sociais, ambientais e mesmo individuais. Um grupo pequeno, mas bastante significativo de filósofos e cientistas sociais não com-

Pontifícia Universidade Católica de São Paulo. 
partilham, contudo, dessa visão otimista em relação às modernas tecnologias, como Herbert Marcuse, Jürgen Habermas, Cornelius Castoriadis, Günther Anders e Hans Jonas entre os filósofos e cientistas sociais como Edgar Morin, Michel Foucault e Bruno Latour. Esses pensadores duvidam da capacidade e do interesse de cientistas e tecnólogos em avaliarem adequadamente os eventuais riscos decorrentes de suas novas tecnologias, desconfiam do uso e do abuso que as instâncias de poder político e econômico poderão fazer dessas tecnologias e conhecimentos e criticam e descreem de uma ciência que se acredita livre de valores e compromissos morais, apenas preocupada com a verdade e o saber.

De fato, se considerarmos a segunda metade do século XX, podemos encontrar excelentes exemplos de tecnologias que se apresentaram inicialmente como grandes invençôes positivas e depois, a posteriori, revelaram seus efeitos colaterais negativos. $\mathrm{O}$ uso de rádio e outros minérios radioativos em pinturas de números de relógios, as centrais nucleares que prometiam uma geração barata e segura de energia, os agrotóxicos e inseticidas organoclorados como o DDT, que se revelaram posteriormente cancerígenos, os aerossóis do tipo dos CFCs, que depletaram a camada de ozônio, as Bifenilas Policloradas (PCBs) utilizadas em capacitores e transformadores elétricos, que também se revelaram cancerígenas e desruptoras endócrinas, e diversos medicamentos que tiveram que ser proibidos quando se descobriram seus efeitos colaterais como o calmante talidomida e vários anti-inflamatórios de uso amplamente disseminado durante décadas.

Atualmente há grande controvérsia científica a respeito dos riscos eventuais ao meio ambiente e à saúde humana dos transgênicos, da nanotecnologia, da biologia sintética, do uso de celulares e de antenas eletromagnéticas. Mas enquanto cientistas e tecnólogos discutem a respeito desses riscos - uns negando-os, outros os afirmando, alimentos transgênicos, cosméticos e outros produtos que se utilizam de nanotecnologia, celulares e antenas eletromagnéticas estão por toda a parte. É possível que daqui há alguns anos, a ciência conclua que se tratavam de tecnologias de alto risco e as autoridades públicas decidam proibi-las. E nessa ocasião, é possível que multimilionários processos jurídicos sejam movidos por associações de vítimas contra empresas e contra os órgãos públicos, por não terem querido e sabido defendê-las, como foi o caso da indústria do tabaco, do amianto e de vários agrotóxicos já retirados de circulação.

A sociedade que produz sistematicamente riscos é uma Sociedade de Risco, afirmou Ulrich Beck, sociólogo alemão, que desenvolveu uma brilhante análise 
crítica sobre os riscos presentes nas modernas tecnologias. Para ele, a sociedade industrial tardia não só disputa a partilha da riqueza produzida entre sindicatos e empregadores, cidadãos e Estado e outros grupos sociais entre si, mas também disputa a distribuiçãao de riscos. Assim, na modernidade avançada, a produção social da riqueza é sistematicamente acompanhada pela produção de riscos. Esses riscos, contudo, são diferentes daqueles que conhecemos no passado, pois enquanto esses últimos eram consequência de carências decorrentes do conhecimento insuficiente dos fenômenos naturais e de tecnologias primitivas, os riscos de hoje são o produto de nosso sucesso científico, de nossas tecnologias de ponta. Não são riscos relacionados com catástrofes naturais, epidemias ou acidentes imprevistos, embora esses continuem a existir, mas riscos oriundos do emprego de tecnologias avançadas como o são os acidentes nucleares, a contaminação química em grande escala, os efeitos colaterais inesperados de drogas e impactos ambientais irreversíveis ou demasiadamente severos. Ou seja, além das preocupações clássicas com a geração e a distribuição de riqueza, preocupações típicas da sociedade capitalista, nossa sociedade tem também que lidar com "os problemas resultantes do próprio desenvolvimento técnico-econômico". A modernização se tornaria, por isso, reflexiva, tornando-se ela mesma o seu próprio tema (Beck 2010).

Além disso, outra diferença entre os riscos antigos e os atuais, é que os primeiros eram riscos pessoais e grupais, enquanto os riscos atuais são globais. De fato, devido à alta tecnologia empregada, seus impactos não se restringem a um determinado espaço e tempo, podendo atingir todo o Planeta e por várias geraçôes futuras. As mudanças climáticas, a depletação da camada de ozônio, a contaminação global com poluentes orgânicos persistentes e a perda crescente de biodiversidade são exemplos desses impactos de longo prazo e larga escala (Beck, 2010).

Há mais outro aspecto no qual os riscos do passado e do presente se distinguem. Os riscos do passado eram evidentes, agredindo olhos, ouvido e olfato, enquanto hoje os riscos escapam à percepção, escondendo-se nas fórmulas físicas e químicas. Por isso, embora suas consequências possam ser muito graves e irreversíveis, eles exigem conhecimento e interpretação científica para serem detectados. São, portanto, "abertos para a definição e construção social", diz Beck (2010), fazendo com que a mídia, cientistas e juristas assumam papéis políticos cruciais. Daí as grandes polêmicas que cercam o debate sobre transgênicos, usinas nucleares, nanotecnologias, biologia sintética ou ondas eletromagnéticas. 
É preciso reconhecer, por isso, que a existência de uma polêmica científica sobre riscos de tecnologias avançadas só existe porque ainda não foi possível alcançar um consenso científico a respeito. A controvérsia sobre os transgênicos é um bom exemplo disso. Efetivamente, a comunidade científica no Brasil e no mundo se divide entre aqueles que acreditam que os transgênicos não trazem riscos à saúde e ao meio ambiente, proporcionando, entretanto, benefícios que iriam desde o combate à fome no mundo até o aumento da produtividade agrícola e ganhos para as economias nacionais e aqueles que são contrários à sua liberação no meio ambiente e na alimentação humana e animal. Estes últimos consideram que é possível que os potenciais riscos daquela tecnologia, que como tecnologia nova carece de estudos sobre os seus impactos em larga escala e de longo prazo na saúde e no meio ambiente, possam superar de muito os seus questionáveis benefícios. Estamos, pois, diante do que se chama uma Controvérsia Científica, aquela situação em que nenhum dos lados tem argumentos suficientemente convincentes para obter o consenso da comunidade científica especializada sobre o assunto (Lacey, 2006).

Não há que se esperar, portanto, que se possa listar vários estudos conclusivos sobre os danos à saúde e ao meio ambiente dos transgênicos, como tampouco seria aceitável a tese de que a ciência até hoje não encontrou nenhum indício de que os transgênicos façam mal. Nenhuma dessas duas posturas corresponderia ao que consideramos como um fundamento da ciência moderna, a famosa Dúvida Metódica, de Descartes. O que sim, é possível mencionar, são alguns poucos estudos nos quais se encontrou indícios de prováveis danos graves à saúde devido ao consumo de transgênicos. Um dos casos mais célebres e mais recente de estudos deste tipo foi o do Professor Gilles-Eric Séralini, cientista francês, que alimentou ratos com um milho transgênico, o NK603, e o herbicida a ele associado e identificou a formação precoce de cânceres nestes ratos em comparação com o grupo de controle sujeito a uma ração normal.

O estudo do professor Seralini sofreu uma bateria de críticas de vários órgãos científicos que normalmente liberam transgênicos e de muitos cientistas e entidades científicas a eles favoráveis. O que aconteceu de mais curioso no seu caso, contudo, é que a revista que publicou o artigo, a Food and Chemical Toxicology retirou-o posteriormente, embora reconhecesse que não houve fraude na sua metodologia ou conteúdo, a única razão pela qual se costuma aceitar a retirada posterior de um artigo que fora previamente submetido ao sistema de per review. $\mathrm{O}$ argumento para a retirada foi que os resultados não eram conclusivos, ou seja, que o 
cientista não poderia provar que a alimentação transgênica gerava cânceres. Bem, não precisamos dizer que se esta for a exigência para que se possa fazer uma afirmação científica, boa parte da ciência desde Francis Bacon deveria ir para a lata de lixo, já que frequentemente o conhecimento científico se constitui a partir do estabelecimento de nexos causais, mesmo que não seja possível explicá-los inicialmente ou conclusivamente, dada a complexidade de certos fenômenos. Mais sugestivo é o fato de que essa revista contratou um especialista em transgênicos vindo da Monsanto, logo em seguida (CARNEIRO, 2015). Uma espécie de censura prévia para esse tema daqui para adiante.

Esse episódio acima descrito nos indica que no que se relaciona com o tema "transgênicos", a controvérsia científica está longe daqueles debates científicos que conhecemos na história da ciência, nos quais por mais acerbas que fossem as pelejas, o ambiente científico no qual elas ocorriam era capaz de impor certo comedimento e respeito. Também é possível constatar que os transgênicos não têm cumprido boa parte das suas promessas. Prometeu-se, por exemplo, que a soja transgênica reduziria o emprego de agrotóxicos, pois a transgenia permitiria que se aplicasse às plantas no pós-plantio agrotóxicos considerados menos tóxicos do que os demais. No caso das plantas BT, a promessa era uma agricultura sem inseticidas, na medida em que essas plantas transgênicas que contém o gene de uma bactéria, o bacilus turingensis, que secreta substância tóxica capaz de eliminar várias pragas.

Contudo, mais de uma década de plantio transgênico no Brasil foi capaz de nos transformar no maior consumidor de agrotóxicos do mundo ${ }^{2}$ e estamos às portas de autorizar uma nova safra de plantas transgênicas- soja e milho - que serão tolerantes não mais aquele supostamente pouco tóxico glifosato, mas ao 2,4,D, fórmula de alta toxicidade e da qual pode originar como subproduto, durante a sua fabricação e depois do seu emprego, dioxinas. E por que? Por que as ervas invasoras se tornaram resistentes ao glifosato, o que não deveria surpreender a ninguém, já que o mecanismo de desenvolvimento de resistência em organismos vivos a substâncias tóxicas é bastante conhecido.

Então, melhor do que discutir impactos na saúde e no meio ambiente dos transgênicos, ou negar a existência de seus impactos, seria importante discutir porque a comunidade científica não é capaz de alcançar um consenso científico a seu respeito. Ou seja, o que nos impede de concluir que há ou não impactos sérios a respeito dos transgênicos.

2 Sindicato Nacional da Indústria de Produtos para a Defesa Agrícola, SINDAG, 2011. 
Em primeiro lugar, do ponto vista da teoria genética, parece que essa se encontra em um momento de transição paradigmática, no qual o dogma de "um gene, uma expressão", está periclitando. Como no livro clássico de Thomas Kuhn, A Estrutura das Revoluçôes Científicas (2010), sabemos que a história das ciências modernas pode ser compreendida como uma sucessão de paradigmas partilhados a cada época pelo conjunto dos seus cientistas. Periodicamente, contudo, o paradigma dominante passa a ser contestado por um novo paradigma, que parece dar conta de maneira mais satisfatória à sua problemática e ao fim, depois de um intenso debate entre os partidários do velho paradigma e um novo, este último se impõe. Certamente esta é uma das razões da atual controvérsia, pois podemos considerar que aquele dogma de "um gene, uma proteína”, está de fato sendo questionado por descobertas recentes. $\mathrm{O}$ problema é que é nele, exclusivamente nele, que se baseia toda a engenharia genética ao pretender introduzir por meio de determinados genes, certas características nas plantas, como tolerância a agrotóxicos e resistência a pragas (Nodari, 2011).

Para explicar a polêmica atual sobre transgênicos, um segundo conjunto de razões também deve ser considerado e que tem a ver não só com um debate sobre paradigmas, mas sobre quem e como se define em nossa época o que é científico, ou melhor, o que corresponderia à verdade científica. Michel Foucault disse certa vez: "a verdade não existe fora do poder ou sem poder”. Ela não é o resultado, portanto, de espíritos livres, que mantiveram a liberdade de pensar. Ela é "desse mundo, produzida nele graças a múltiplas coerçôes e nela produz efeitos regulamentados de poder" (1981, p. 12).

Ao expressar-se dessa maneira, Foucault se refere às relações de poder, que presentes no discurso científico, nas práticas e nas instituições, permitem que se diga ou se aceite tal ou qual teoria como científica em dada época, e que outras sejam descartadas. Exemplo disso, nos dias de hoje, é o fato de que não se considere os conhecimentos sobre agricultura de povos indígenas e camponeses, que foram os primeiros a domesticar plantas e animais, porque não são alfabetizados, não dominam a língua portuguesa, não estudaram em escolas de agronomia e não tem Currículo Lattes. Quem se considera capaz de falar atualmente sobre agricultura são pessoas que estudaram agronomia, pertencem a instituições científicas ou a empresas agrícolas e publicam em revistas especializadas. E que frequentemente já fizeram seus estágios em empresas produtoras de sementes, agrotóxicos e insumos agrícolas. Não que grande parte do que se aprenda nos cursos de agronomia e genética não corresponda aos fatos, ou melhor, que os fatos pareçam ser explicados por suas teorias, pois isso também valeria para qualquer outra explicação que 
possamos considerar como mágica ou religiosa. É que só esse tipo de discurso e de instituições valem como ciência, como verdade em nossa época.

Além desse aspecto, Foucault dirá que a ciência em nossa época está submetida a uma constante incitação econômica e política, é objeto de uma imensa difusão e de um intenso consumo e é produzida e transmitida sob o controle, não exclusivo, mas dominante, de alguns grandes aparelhos políticos ou econômicos como a universidade, as forças armadas e meios de comunicação, sendo por fim objeto de debate político e de confronto social.

A referência à incitação econômica e política pode ajudar-nos a compreender porque a polêmica em torno dos transgênicos frequentemente assume feiçôes tão agressivas, e por vezes até incivilizadas. Os produtores de transgênicos resumem-se a cinco ou seis grandes empresas transnacionais, que produzem sementes, agrotóxicos e medicamentos: Monsanto, Syngenta, Du Pont, Bayer, Basf. Seus principais consumidores são a grande agricultura empresarial, produtora de commodities e estreitamente associada aos grandes intermediários do comércio mundial, que tem constituído verdadeiros “impérios alimentares" (Petersen, 2009), penetrando em toda a cadeia produtiva, desde o plantio, passando pela comercialização, processamento, e distribuição de alimentos no atacado e no varejo. Os lucros dessas empresas são gerados pela venda de "produtos" para os quais obtiveram um monopólio, graças à legislação de propriedade intelectual que concede ao "inventor" - essas empresas - o direito de cobrarem pelo uso de suas tecnologias. A razão da tecnologia, portanto, é muito menos o que ela pode fazer - tolerar agrotóxicos, resistir a pragas, produzir alimentos mais nutritivos ou aumentar a produtividade e o rendimento de cultivos - do que possuir algo do qual uma empresa ou indivíduo possa reivindicar ser o inventor e, portanto, o dono (Lisboa, 2008).

A prova dos nove dessa tese é simplesmente imaginar qual seria o teor do debate sobre transgênicos, caso ele se desenrolasse apenas no ambiente acadêmico, sob a condição de que tal tecnologia não fosse introduzida no meio ambiente e na alimentação humana antes que vencesse uma moratória de várias décadas. A discussão provavelmente seria tão enfadonha quanta aquela sobre o sexo dos anjos ou a querela dos universais na Idade Média, nos parece hoje.

A controvérsia sobre os transgênicos, portanto, é sobretudo um debate político e de "confronto social". Camponeses e agricultores familiares que não desejam e não podem concorrer com essa agricultura de insumos caros, consumidores, ambientalistas e nutricionistas opóem-se aos transgênicos. De ambos lados, temos cientistas exibindo seus argumentos, pesquisas e estudos. 
Como afirma Ulrick Beck, em temas como esses, a própria comunidade científica se divide e se dilacera, pois em uma sociedade onde só a Ciência é considerada como verdade, o conflito de interesses econômicos e políticos tem que assumir a feição de discurso científico. Mas, para defender o emprego imediato e em larga escala desta tecnologia, - algo que não tem a ver com a ciência, mas com a economia - seus propagandistas acabam por negar princípios fundamentais do próprio discurso científico moderno, como afirmar que tais tecnologias são $100 \%$ seguras. Recusam-se até a realizar experiências científicas que poderiam trazer resultados não desejáveis e utilizam-se de argumentos capciosos e externos ao debate científico, como o da explosão demográfica, dos interesses econômicos do país e da concorrência nos mercados internacionais.

Considerando, portanto, as condições sociais em que se produz ciência nos nossos dias, é preciso abandonar a visão ingênua a seu respeito e sobre as novas tecnologias. Os objetivos e o financiamento da pesquisa e desenvolvimento tecnológico atualmente não são definidos em virtude das prioridades e necessidades da humanidade, mas dos lucros privados que elas possam arrojar e dos usos políticos que delas se possam fazer. Cientistas e tecnólogos são hoje assalariados de empresas e órgãos estatais ou empresários que vendem seus conhecimentos patenteados a essas empresas e órgãos. Doenças socialmente negligenciadas são exemplo de que não são as prioridades sociais o que orienta a pesquisa científica. Estimula-se as instituições acadêmicas, mesmo às públicas, a desenvolverem a pesquisa científica que permita privatizar os conhecimentos obtidos por meio de patentes e de parcerias com empresas privadas. Por isso, embora presente em leis e Convenções de meio ambiente, não se adota efetivamente o Princípio da Precaução. Esse princípio, que exige que autoridades públicas hajam para evitar a ameaça de danos graves ou irreversíveis, mesmo quando não haja plena certeza desses danos - uma espécie de "em dúvida pro meio ambiente e saúde humana”, é hoje elemento básico da legislação ambiental, estando presente em todas as Convenções e Declarações de Meio Ambiente firmadas internacionalmente (Harremöes, 2002; Whiteside, 2006).

Finalmente, é preciso entender que os riscos da Sociedade de Risco, assumidos em função dos interesses econômicos e políticos, quando ocorrem, além de afetarem pessoas e meio ambiente, condição de vida dessas pessoas, também produzem efeitos negativos sobre esses próprios interesses econômicos e políticos. Empresas quebram, economias nacionais se abalam, políticos e governos caem. As mudanças climáticas, a poluição global e a destruição da biodiversidade hoje ameaçam toda a 
civilização industrial criada nos últimos 200 anos. A Sociedade de Risco, como diz Beck, mina as fronteiras dos Estados-Nação, bem como aquelas das alianças militares e blocos econômicos, instaurando "comunidades de riscos" e permitindo que se construa uma sociedade mundial, uma "comunidade de risco", que colide com egoísmos nacionais e interesses de grupos. O caráter verdadeiramente internacional dos movimentos ambientalistas, é prova disso.

Os objetivos da Sociedade de Risco, assim, são diferentes daqueles das sociedades de riqueza. Enquanto essas buscavam e deveriam continuar buscando a redução das desigualdades sociais, a Sociedade do Risco busca a segurança e a defesa de condições saudáveis de existência da vida no Planeta. É uma aposta, contudo, se na defesa desse bem maior que é a vida, a humanidade será capaz de libertar a técnica das imposições do lucro e desenvolver uma ciência amante da precaução.

\section{REFERÊNCIAS}

BECK, U., Sociedade de Risco: rumo a uma outra modernidade, São Paulo, Editora 34, 2010.

CARNEIRO, F.F., AUGUSTO L., RIGOTTO R., FRIEDRICH K., BURIGO A.C. (Org.), Dossiê ABRASCO: um alerta sobre os impactos de agrotóxicos na saúde, RJ, Escola Politécnica de Saúde Joaquim Venâncio/Expressão Popular, 2015.

FOUCAULT, M., Microfísica do poder, RJ, Ediçōes Graal, 2. ed., 1981.

HARREMOËS, P et. al., (Org.) The Precautionary Principle in the 20th Century: late lessons from early warnings, London, Earthscan Publications, 2002.

KUHN, T., A Estrutura das revoluções científicas, São Paulo, Perspectiva, 2010.

LACEY, H., A Controvérsia sobre os Transgênicos: questōes científicas e éticas, São Paulo, Ideias \& Letras, 2006.

LISBOA, M., Cultura e Natureza: o que o software tem a ver com os transgênicos? Além das redes de colaboração: internet, diversidade cultural e tecnologias de poder, Salvador, EDUFBA, 2008.

NODARI, R., Ciência Precaucionária como Alternativa ao Reducionismo Científico Aplicado à Biologia Molecular. In: ZANONI, M., FERMENT. G. Transgênicos para quem? Agricultura, Ciência e Sociedade. Brasília, DF: Ministério do Desenvolvimento Agrário, 2011.

PETERSEN, P., Agriculturas ou Impérios Alimentares? Uma encruzilhada no Caminho da Humanidade. PUCViva, Agricultura no Brasil, São Paulo, setembro/dezembro 2009.

WHITESIDE, K., Precautionary politics: principle and practice in confronting environmental risk, Cambridge/London, The MIT Press, 2006. 
